\title{
KARAKTERISTIK MINERAL LEMPUNG HASIL UBAHAN PADA SUMUR LW-1 DAN LW-2 DENGAN MENGGUNAKAN METODE DIFRAKSI SINAR-X PADA SISTEM PANAS BUMI GUNUNG LAWU
}

\author{
THE CHARACTERISTICS OF CLAY MINERAL ALTERATION FROM \\ WELLS LW-1 AND LW-2 USING X-RAY DIFFRACTION METHOD \\ IN THE MOUNT LAWU GEOTHERMAL SYSTEM
}

\author{
Lano Adhitya Permana, Candra Widya Sastrawijaya, dan Dudi Hermawan \\ Pusat Sumber Daya Mineral, Batubara dan Panas Bumi \\ lano.adhitya@esdm.go.id
}

\begin{abstract}
ABSTRAK
Sumur panas bumi LW-1 dan LW-2 yang terletak pada zona depresi antara Gunung Lawu dan Gunung Jabolorangan memiliki batuan yang telah mengalami ubahan hidrotermal, dicirikan dengan mineral-mineral ubahan yang tergolong ke dalam tipe ubahan argilik-argilik lanjut. Untuk mengetahui karakter mineral ubahan yang terbentuk, khususnya kehadiran mineral lempung pada sumur LW-1 dan LW-2, maka diperlukan studi mengenai mineral lempung dengan menggunakan pendekatan metode difraksi sinar-X ( $X$-Ray Diffraction/XRD). Penelitian ini bertujuan untuk mengetahui keterdapatan dan karakteristik mineral lempung pada sumur LW-1 dan LW-2 serta hubungannya dengan pembentukan sistem panas bumi di daerah Gunung Lawu. Penggunaan metode XRD pada sumur LW-1 dan LW-2 menunjukkan bahwa pada saat temperatur mengalami peningkatan maka bentuk kristal dari mineral lempung semakin sempurna yang kemudian diikuti oleh semakin kecilnya nilai derajat kristalinitas, sedangkan pengaruh ukuran butir pada pola XRD memperlihatkan bahwa derajat kristalinitas mineral lempung cenderung mengalami penurunan seiring dengan bertambahnya ukuran butir. Mineral lempung hasil ubahan pada sumur LW-1 dan LW-2 terdiri dari smektit, illit, kaolinit dan haloisit yang dapat berfungsi sebagai lapisan penudung dalam sistem panas bumi Gunung Lawu.
\end{abstract}

Kata kunci: XRD, mineral lempung, derajat kristalinitas, temperatur, lapisan penudung, Gunung Lawu

\section{ABSTRACT}

The $L W-1$ and $L W-2$ geothermal wells are located in the depression zone between Mount Lawu and Mount Jabolorangan contain rocks that are hydrothermally alterated as indicated by the presence of alteration minerals that are classified as argillic to advanced argillic alteration. To determine the character of the altered minerals that were formed, especially the presence of clay minerals in LW-1 and LW-2 wells, a study of clay minerals is required using the X-Ray Diffraction approach. This study aims to determine the presence and characteristics of clay minerals in LW-1 and LW-2 also their correlation to the formation of a geothermal system in the Gunung Lawu area. The analysis and interpretation using XRD method in $L W-1$ and $L W-2$ wells shows that within the temperature increases the crystal shape of the clay minerals becomes more perfect which is represented by a smaller degree of crystallinity. Whereas the effect of grain size on the XRD pattern shows that the crystallinity of the clay minerals tend to decrease with increasing grain size. The altered clay minerals in $L W-1$ and $L W-2$ wells consist of smectite, illite, kaolinite and halloysite which can be acted as caprock in the Mount Lawu geothermal system.

Keywords: XRD, clay minerals, degree of crystallinity, temperature, caprock, Mount Lawu 


\section{PENDAHULUAN}

Keberadaan jalur vulkanik yang terdapat di sepanjang Pulau Jawa memberikan peluang terbentuknya sistem panas bumi di sepanjang jalur tersebut, salah satunya seperti yang terdapat di daerah Gunung Lawu yang terletak di perbatasan Provinsi Jawa Tengah dan Provinsi Jawa Timur. Sistem panas bumi Gunung Lawu diduga terkait dengan adanya aktivitas vulkanik termuda Gunung Lawu yang masih menyimpan sisa panas dari dapur magma (Anonim, 2009). Sisa panas tersebut berperan sebagai sumber panas yang memanasi fluida di bawah permukaan, untuk kemudian naik melalui rekahan sehingga terjadi proses interaksi antara fluida panas dan batuan yang mengakibatkan batuan mengalami ubahan. Kehadiran batuan ubahan tersebut dapat menjadi indikasi bahwa telah terjadi proses hidrotermal, seperti yang tampak pada sumur LW-1 dan LW-2.

Sumur LW-1 dan LW-2 terletak di selatan Gunung Lawu, tepatnya pada zona depresi antara Gunung Lawu dan Gunung Jabolorangan (Anonim, 2010a dan 2010b). Pengeboran sumur LW-1 dan LW-2 yang masing-masing mencapai kedalaman 243 $\mathrm{m}$ dan $253 \mathrm{~m}$, dilakukan secara vertikal oleh Pusat Sumber Daya Geologi - Badan Geologi pada tahun 2010.

Browne (1999) menyebutkan bahwa ubahan hidrotermal merupakan hasil interaksi antara fluida panas dan batuan dalam suatu sistem panas bumi yang dapat membentuk deretan mineral hidrotermal pada kondisi fisika dan kimia tertentu. Mineral lempung sebagai salah satu produk ubahan hidrothermal sering digunakan sebagai indikator untuk menentukan tipe dan temperatur fluida saat berinteraksi dengan batuan sekitarnya. Untuk mengetahui karakter mineral ubahan yang terbentuk, khususnya kehadiran mineral lempung pada sumur LW-1 dan LW-2, maka diperlukan studi mineral lempung dengan pendekatan metode difraksi sinar-X (X-Ray Diffraction/XRD). Keunggulan penggunaan metode $X R D$ yaitu dapat mengidentifikasi berbagai jenis mineral lempung secara jelas dan akurat. Penelitian ini bertujuan untuk mengetahui karakteristik dan keterdapatan mineral lempung pada sumur LW-1 dan LW-2 berdasarkan metode XRD serta hubungannya terhadap pembentukan sistem panas bumi Gunung Lawu.

\section{METODOLOGI}

Metode yang digunakan pada penelitian ini difokuskan pada pengolahan data XRD terhadap 27 conto batuan yang berasal dari sumur LW-1 dan LW-2, untuk kemudian dapat dianalisis bersama dengan data petrografi. Analisis petrografi dengan menggunakan mikroskop polarisasi dilakukan agar dapat diketahui jenis batuan dan mineral sekunder yang terbentuk serta intensitas ubahannya. Sedangkan, untuk mengetahui kehadiran mineral lempung yang tidak bisa ditentukan jenisnya secara petrografis dapat dilakukan melalui analisis XRD.

Moore dan Reynolds (1997) menyebutkan bahwa analisis XRD yang menggunakan spektrum sinar- $X$ dengan panjang gelombang sekitar $20 \mu \mathrm{m}-2 \mathrm{~nm}$ sangat cocok untuk mengidentifikasi mineral lempung, hal ini dikarenakan mineral lempung mempunyai ukuran yang sangat halus (kurang dari $2 \mu \mathrm{m}$ ). Dalam penelitian ini, analisis XRD menggunakan perangkat mesin Shimadzu type XRD-7000 dengan kondisi pengoperasian pada $40 \mathrm{kV}$ dan 40 $\mathrm{mA}$ serta radiasi CuKa $\left(\lambda_{1}=1,5406 \AA\right)$. Seluruh conto mineral lempung yang digunakan dalam penelitian ini, dianalisis XRD secara bulk powder. Preparasi bulk powder dilakukan pada conto batuan dalam kondisi kering. Cuplikan dari conto batuan yang dianggap representatif akan dipreparasi terlebih dahulu dengan cara ditumbuk untuk kemudian dihaluskan dengan tema mill hingga dapat lolos melalui ayakan penyaring berukuran 200 mesh. Selanjutnya, dilakukan penggerusan 
hingga menjadi serbuk sangat halus berukuran lempung. Serbuk sangat halus hasil penggerusan, diletakkan ke dalam sample holder. Setelah seluruh rangkaian preparasi dengan metode bulk powder dilakukan, conto mineral lempung sudah dapat digunakan pada perangkat mesin analisis XRD.

Identifikasi mineral lempung melalui analisis XRD dapat dilakukan melalui pencocokan posisi puncak difraksi dengan data yang terdapat pada standar Powder Diffraction File (PDF). Dalam penelitian ini, interpretasi mineral lempung berdasarkan pola XRD mengacu pada Moore dan Reynolds (1997), seperti yang tampak pada Gambar 1. Posisi puncak difraksi, tinggi puncak difraksi, lebar dan bentuk puncak difraksi serta intensitas difraksi merupakan hal yang sangat diperhatikan dalam mengidentifikasi mineral lempung.

Sementara itu, Eberl and Velde (1989) menjelaskan bahwa untuk mengukur kristalinitas suatu mineral dapat menggunakan lebar pada setengah peak XRD (Full Width Half Maximum/FWHM), seperti yang ditunjukkan pada Gambar 2. FWHM merupakan parameter yang digunakan untuk menghitung derajat kristalinitas. Nilai derajat kristalininitas dikenal juga sebagai indeks Kubler, biasa dinyatakan dalam ${ }^{0} \Delta 2 \theta$. Seluruh analisis XRD dan petrografi dilakukan di Laboratorium Pusat Sumber Daya Mineral Batubara Panas Bumi, Badan Geologi Bandung.

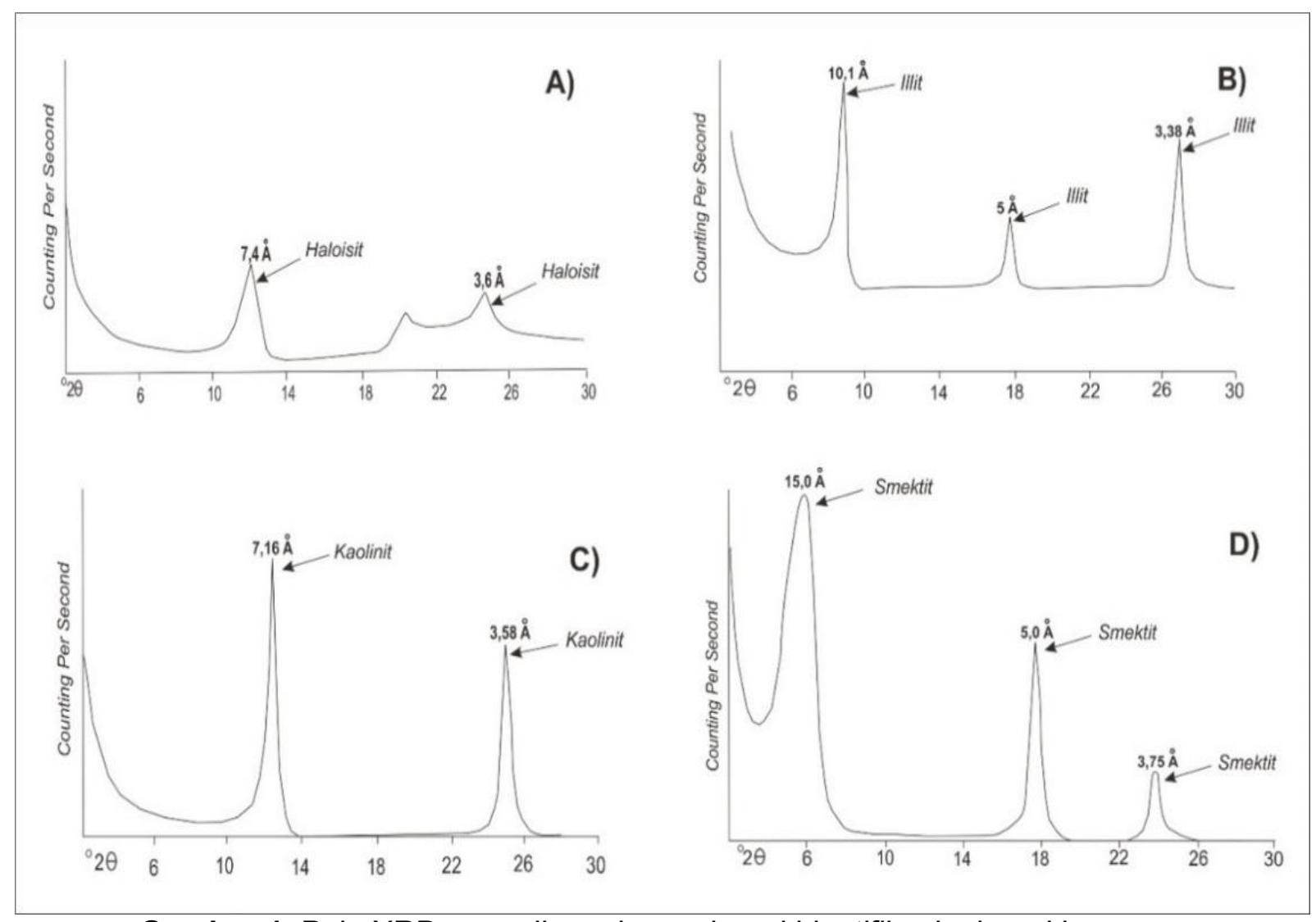

Gambar 1. Pola XRD yang digunakan sebagai identifikasi mineral lempung pada sumur penelitian (Modifikasi dari Moore dan Reynolds, 1997) 


\section{MAKALAH ILMIAH}

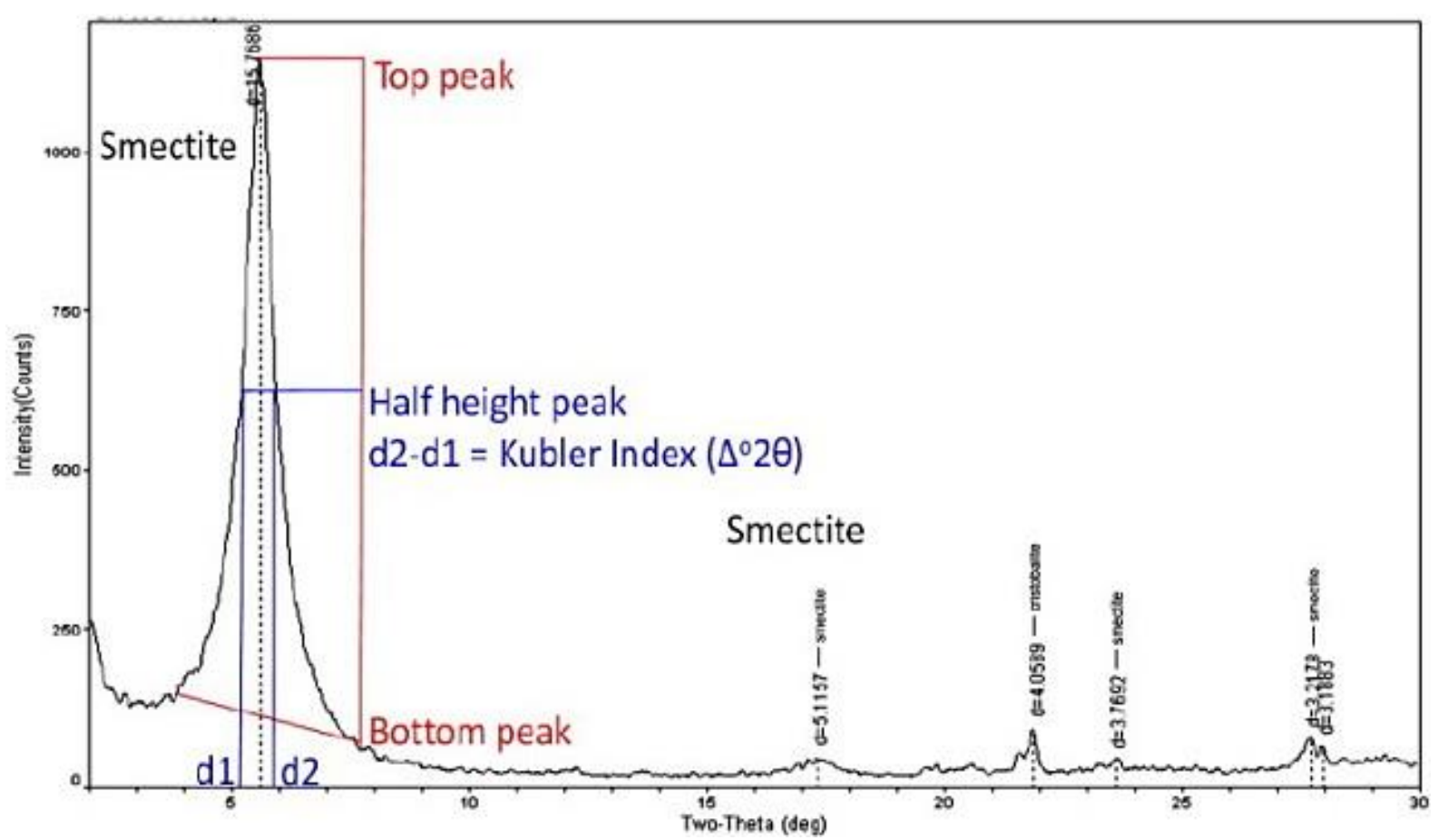

Gambar 2. Contoh pengukuran kristalinitas pada mineral lempung (smektit). Derajat kristalinitas diukur sebagai lebar pada setengah intensitas maksimum

(Modifikasi dari Prasetyo,dkk., 2015)

\section{GEOLOGI}

Gunung Lawu termasuk dalam gunung api Kuarter yang terbentuk akibat adanya penunjaman Lempeng Indo-Australia yang menyusup dibawah Lempeng Eurasia (Hamilton, 1979). Secara umum, geologi daerah penelitian tersusun oleh batuan sedimen, batuan intrusi dan batuan vulkanik serta endapan permukaan yang berumur Tersier hingga Kuarter (Anonim, 2009). Pada daerah penelitian terdapat beberapa pusat erupsi yang dapat menghasilkan produk batuan vulkanik berumur Kuarter, seperti yang berasal dari Gunung Jabolarangan, Gunung Lawu, Gunung Purung dan Gunung Anak. Secara umum, jenis batuan vulkanik di daerah penelitian terdiri dari aliran lava, aliran piroklastik dan kubah lava. Aliran lava dan kubah lava yang terbentuk di daerah penelitian memiliki komposisi andesitik hingga basaltik, sedangkan aliran piroklastik memiliki komponen berupa fragmen litik, tuff dan breksi (Anonim, 2009). Lebih Lanjut, Anonim (2009) menjelaskan bahwa struktur geologi yang teramati di daerah Gunung Lawu berupa Rim kawah di daerah puncak Gunung Jobolarangan yang merupakan bidang runtuh (collapse) dan sesar-sesar normal berarah barat-timur serta berarah utara-selatan yang mengontrol kemunculan manifetasi panas bumi di daerah penelitian (Gambar 3). Manifestasi permukaan yang dijumpai di daerah Gunung Lawu berupa mata air panas bertemperatur $32,4^{\circ} \mathrm{C}$ s.d. $94^{\circ} \mathrm{C}$ dan fumarol dengan temperatur sekitar $93^{\circ} \mathrm{C}$ serta ubahan hidrotermal dengan tipe ubahan berupa argilik-argilik lanjut (Anonim, 2009). 

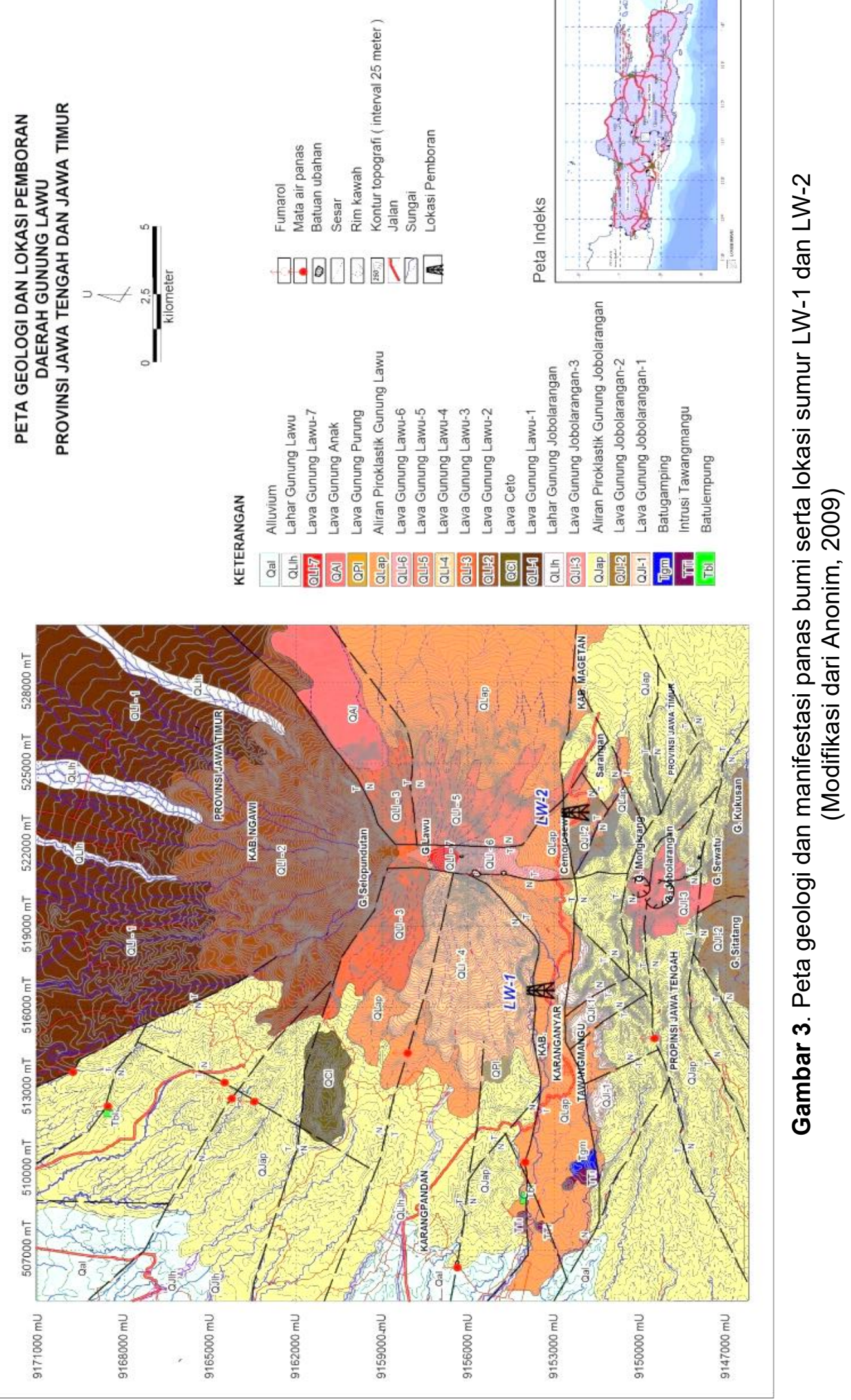


\section{MAKALAH ILMIAH}

Anonim (2010a, 2010b) menyebutkan bahwa litologi bawah permukaan yang terdapat pada sumur LW-1 dan LW-2 terdiri dari Breksi Tuf, Basalt, Breksi Tuf Terubah, Basalt Terubah, Andesit, dan Andesit Terubah (Gambar 4 dan 5). Pada sumur LW-1, breksi tuf dijumpai pada kedalaman 6 m s.d. 25 m, 69 m s.d. $74,4 \mathrm{~m}$ dan 138,20 $\mathrm{m}$ s.d. $161,20 \mathrm{~m}$, sedangkan pada sumur LW-2 satuan ini dijumpai pada kedalaman $3 \mathrm{~m}$ s.d. $25 \mathrm{~m}$. Kehadiran basalt dan basalt terubah hanya ditemukan di sumur LW-1, dalam hal ini basalt dijumpai pada kedalaman $25 \mathrm{~m}$ s.d. $69 \mathrm{~m}, 74,4 \mathrm{~m}$ s.d.138,20 m dan 161,2 m s.d. 166,5 m, sedangkan basalt terubah hadir s.d. kedalaman 203,5 m, dan kedalaman 208,80 m s.d. 242,95 m. Breksi tuf terubah ditemukan pada kedalaman $166,40 \mathrm{~m}$ s.d. $196,60 \mathrm{~m}$ dan $203,50 \mathrm{~m}$ s.d. $208,80 \mathrm{~m}$ di sumur LW-1, sedangkan pada sumur LW-2 dijumpai di kedalaman 103 m s.d. 145 m, $170,80 \mathrm{~m}$ s.d. $237 \mathrm{~m}$, dan $248,90 \mathrm{~m}$ s.d. $252 \mathrm{~m}$. Sementara itu, keterdapatan andesit dan andesit terubah hanya dijumpai pada sumur LW-2. Andesit ditemukan pada kedalaman 25 m s.d. 103 $\mathrm{m}$, sedangkan andesit terubah dijumpai di kedalaman $145 \mathrm{~m}$ s.d. $170,80 \mathrm{~m}$ dan $237 \mathrm{~m}$ s.d. $248,9 \mathrm{~m}$.

Menurut Permana (2011), komposisi mineral ubahan hidrotermal yang hadir pada sumur LW-1 dan LW-2 terbagi menjadi beberapa jenis, yaitu mineral silika (kristobalit, kalsedon, kuarsa sekunder dan tridimit), karbonat (kalsit dan siderit), mineral opak, oksida besi, idingsit, stilpnomelan dan mineral lempung (Gambar 4 dan Gambar 5). Lebih lanjut, Permana (2011) menyebutkan bahwa litologi bawah permukaan pada sumur LW1 dan LW-2 telah mengalami ubahan hidrotermal dengan intensitas lemah hingga kuat dan memiliki tipe ubahan berupa argilik-argilik lanjut.

\section{HASIL DAN PEMBAHASAN}

Hasil analisis XRD pada batuan di sumur LW-1 dan LW-2, menunjukkan kehadiran mineral lempung hasil ubahan hidrotermal yang terdiri dari haloisit, kaolinit, smektit dan Illit (Tabel 1).

Haloisit merupakan mineral hasil ubahan yang dapat mengindikasikan kehadiran fluida asam di masa lampau dengan temperatur pembentukan kurang dari $120^{\circ} \mathrm{C}$ (Kingstone Morrison, 1995) dan merupakan penciri tipe zona ubahan argilik hingga argilik lanjut (Corbett dan Leach, 1998). Pada sumur LW-1 haloisit muncul mulai di kedalaman $13 \mathrm{~m}$ s.d. $167 \mathrm{~m}$ dan kedalaman 213 m s.d. 242 m (Gambar 4). Namun untuk sumur LW-2, kehadiran haloisit hampir muncul di semua kedalaman (Gambar 5). Hasil analisis XRD di kedalaman $121 \mathrm{~m}$ pada sumur LW-2 (Gambar 6), menunjukkan bahwa haloisit berada di 7,25 $\AA$ untuk basal pertama dan pada $3,63 \AA$ untuk basal kedua. 


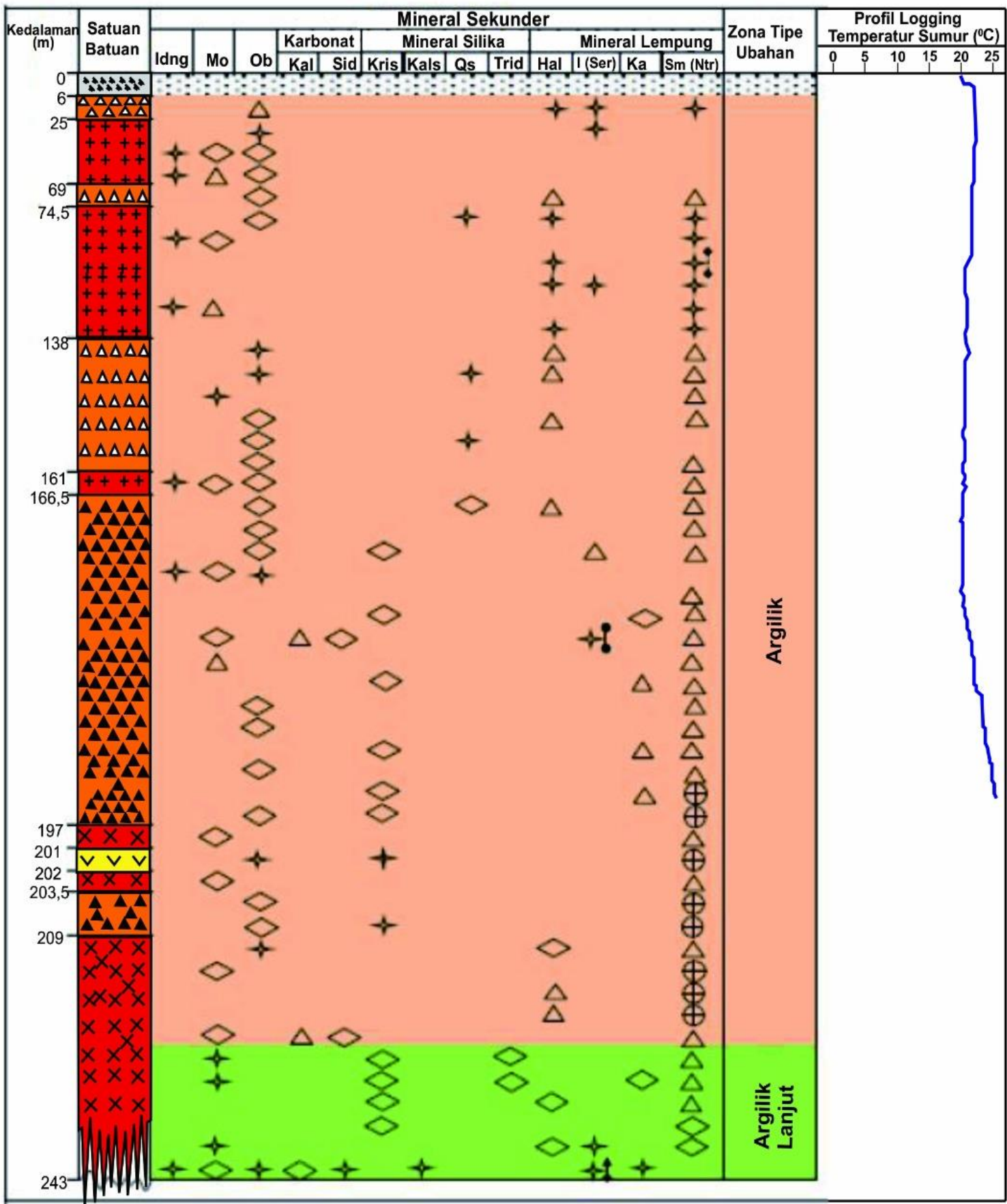

\section{Keterangan:}

\begin{tabular}{|c|c|c|c|c|c|c|c|}
\hline$+++t$ & Basalt & Hal & $\begin{array}{l}=\text { Haloisit } \\
=\|\| \text { lit }\end{array}$ & $\begin{array}{l}\mathrm{Ob} \\
\mathrm{Qs}\end{array}$ & $\begin{array}{l}=\text { Oksida Besi } \\
=\text { Quarsa Sekunder }\end{array}$ & i & $\begin{array}{l}=1 \text { Idak Terdapat Analisis } \\
=\text { Serisit }\end{array}$ \\
\hline$x$ & Basalt Terubah & Idng & $=$ Idingsit & Ser & $=$ Serisit & $\uparrow$ & \\
\hline$\overline{\Delta \Delta \Delta \Delta \Delta \Delta}$ & Basalt Tufa & Ка & = Kaolinit & Sid & $=$ Siderit & $t$ & $=$ Illit - Serisit \\
\hline$\overline{Q A B}$ & Basalt Tufa Terubah & Kals & = Kalsedon & Sm & $=$ Smektit & ? & = Smektit - Nontronit \\
\hline$\vee \vee v$ & Tufa & Mo & = Mineral Opak & Trid & $\begin{array}{l}=\text { Tridimit } \\
=\text { Grafik }\end{array}$ & $\leftrightarrow$ & $\begin{array}{l}=<5 \% \text { (Jarang) } \\
=5-10 \% \text { (Sedikit) }\end{array}$ \\
\hline & Zona Argilik & & $=$ Nontronit & & Ten & $\triangle$ & $=10-25 \%$ (Sedang) \\
\hline & Zona Argilik Lanjut & & & & & $\oplus$ & $=>25 \%$ (Banyak) \\
\hline
\end{tabular}

Gambar 4. Distribusi mineral sekunder sumur LW-1

(Modifikasi dari Permana, 2011 dan Anonim, 2010a) 


\section{MAKALAH ILMIAH}

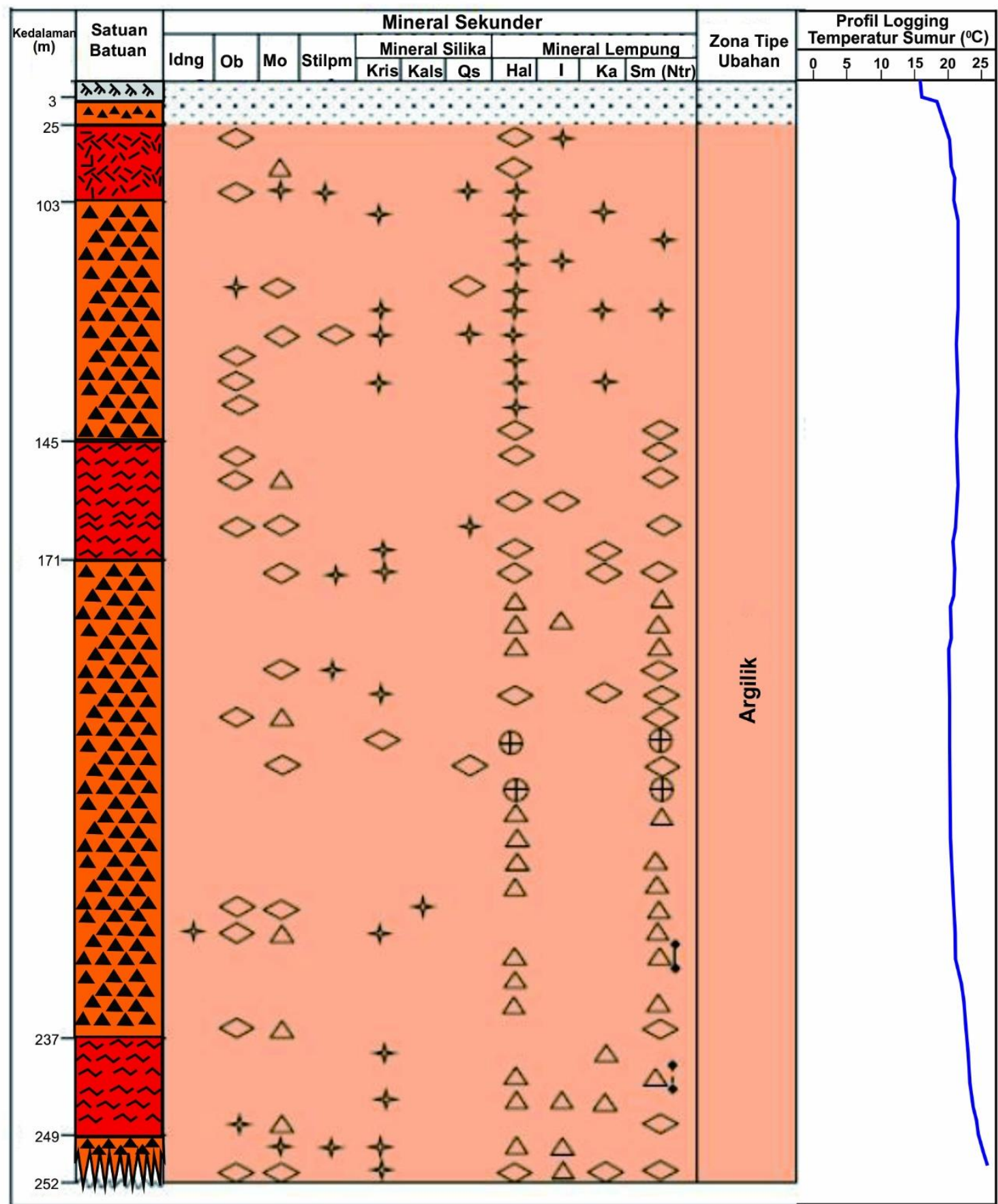

Keterangan:

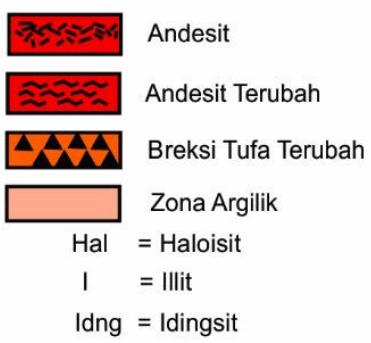

$\begin{aligned} \mathrm{Ka} & =\text { Kaolinit } \\ \mathrm{Kals} & =\text { Kalsedon } \\ \mathrm{Kris} & =\text { Kristobalit } \\ \mathrm{Mo} & =\text { Mineral Opak } \\ \mathrm{Ntr} & =\text { Nontronit } \\ \mathrm{Ob} & =\text { Oksida Besi } \\ \mathrm{Qs} & =\text { Quarsa Sekunder } \\ \mathrm{Sm} & =\text { Smektit }\end{aligned}$

$$
\begin{aligned}
& \text { mexe }=\text { Tidak Terdapat Analisis } \\
& -=\text { = Grafik Logging } \\
& \text { I = Serisit } \\
& \text { = Illit }- \text { Serisit } \\
& \text { ‡ = Smektit - Nontronit } \\
& \text { 支 }=<5 \% \text { (Jarang) } \\
& \diamond=5-10 \% \text { (Sedikit) } \\
& \triangle=10-25 \% \text { (Sedang) } \\
& \bigoplus=>25 \% \text { (Banyak) }
\end{aligned}
$$

Gambar 5. Distribusi mineral sekunder sumur LW-2

(Modifikasi dari Permana, 2011 dan Anonim, 2010b) 
Tabel 1. Karakteristik difraksi sinar-X pada mineral lempung di sumur LW-1 dan LW-2

\begin{tabular}{|c|c|c|c|c|c|}
\hline$\frac{\text { Kedalaman }}{(\mathrm{m})}$ & $\begin{array}{c}\text { Ketebalan Unit Sel } \\
\text { (d spacing) }\end{array}$ & Mineral Lempung & 00\lceil & ${ }^{0} \Delta 2 \theta$ & $\mathbf{L}$ \\
\hline \multicolumn{6}{|c|}{ LW-1 } \\
\hline 153 & 2,99 & Smektit & 003 & 0,500 & 168,52 \\
\hline \multirow{2}{*}{167} & 4,48 & \multirow{2}{*}{ Smektit } & 002 & 0,300 & 280,87 \\
\hline & 3,00 & & 003 & 0,300 & 286,36 \\
\hline 172 & 9,89 & Illit & 001 & 0,400 & 208,09 \\
\hline \multirow{5}{*}{177} & 14,96 & \multirow{3}{*}{ Smektit } & 001 & 0,750 & 110,79 \\
\hline & 4,48 & & 002 & 0,500 & 168,52 \\
\hline & 2,99 & & 003 & 0,300 & 286,36 \\
\hline & 7,07 & \multirow{2}{*}{ Kaolinit } & 001 & 0,300 & 278,25 \\
\hline & 3,73 & & 002 & 0,200 & 424,57 \\
\hline \multirow{3}{*}{180} & 14,96 & \multirow{3}{*}{ Smektit } & 001 & 0,800 & 103,87 \\
\hline & 4,48 & & 002 & 0,400 & 210,65 \\
\hline & 3,02 & & 003 & 0,300 & 286,36 \\
\hline \multirow{4}{*}{187} & 14,96 & \multirow{3}{*}{ Smektit } & 001 & 0,900 & 92,33 \\
\hline & 4,48 & & 002 & 0,300 & 280,87 \\
\hline & 2,99 & & 003 & 0,200 & 429,54 \\
\hline & 7,07 & Kaolinit & 001 & 0,200 & 417,38 \\
\hline \multirow{5}{*}{190} & 14,96 & \multirow{3}{*}{ Smektit } & 001 & 0,900 & 92,33 \\
\hline & 4,48 & & 002 & 0,300 & 280,87 \\
\hline & 3,02 & & 003 & 0,200 & 429,54 \\
\hline & 7,07 & \multirow{2}{*}{ Kaolinit } & 001 & 0,200 & 417,38 \\
\hline & 3,73 & & 002 & 0,100 & 849,13 \\
\hline \multirow{3}{*}{196} & 14,96 & \multirow{3}{*}{ Smektit } & 001 & 0,900 & 92,33 \\
\hline & 4,48 & & 002 & 0,400 & 210,65 \\
\hline & 3,02 & & 003 & 0,300 & 286,36 \\
\hline \multirow{3}{*}{201} & 14,96 & \multirow{3}{*}{ Smektit } & 001 & 0,900 & 92,33 \\
\hline & 4,48 & & 002 & 0,400 & 210,65 \\
\hline & 3,02 & & 003 & 0,300 & 286,36 \\
\hline & 14,96 & & 001 & 0,900 & 92,33 \\
\hline 206 & 4,48 & Smektit & 002 & 0,400 & 210,65 \\
\hline & 3,02 & & 003 & 0,300 & 286,36 \\
\hline & 15,51 & & 001 & 0,700 & 118,71 \\
\hline 229 & 4,45 & Smektit & 002 & 0,400 & 210,65 \\
\hline & 3,01 & & 003 & 0,300 & 286,36 \\
\hline & 15,49 & & 001 & 0,700 & 118,71 \\
\hline 234 & 4,43 & Smektit & 002 & 0,500 & 168,52 \\
\hline & 3,00 & & 003 & 0,300 & 286,36 \\
\hline & 14,96 & & 001 & 0,900 & 92,33 \\
\hline 239 & 4,48 & Smektit & 002 & 0,400 & 210,65 \\
\hline & 3,02 & & 003 & 0,300 & 286,36 \\
\hline & 15,10 & & 001 & 0,600 & 138,49 \\
\hline 241 & 4,67 & Smektit & 002 & 0,300 & 280,87 \\
\hline & 2,99 & & 003 & 0,200 & 429,54 \\
\hline & & LW-2 & & & \\
\hline 103 & 7,24 & Kaolinit & 001 & 0,900 & 92,75 \\
\hline 115 & 7,13 & Kaolinit & 001 & 0,400 & 208,69 \\
\hline 115 & 4,43 & Kaoınit & 002 & 0,300 & 280,65 \\
\hline 121 & 7,25 & Haloisit & 001 & 0,800 & 104,30 \\
\hline 121 & 3,63 & Haloısıt & 002 & 0,200 & 424,37 \\
\hline & 7,13 & & 001 & 0,700 & 119,25 \\
\hline 128 & 3,61 & Kaolinit & 002 & 0,300 & 280,65 \\
\hline & 2,30 & & 003 & 0,200 & 424,57 \\
\hline & 7,24 & & 001 & 0,400 & 208,69 \\
\hline 162 & 4,43 & Kaolınıt & 002 & 0,200 & 420,98 \\
\hline & 9,92 & Illit & 001 & 0,200 & 416,18 \\
\hline 171 & 7,24 & & 001 & 0,600 & 139,13 \\
\hline & 4,43 & Kaolinit & 002 & 0,300 & 280,65 \\
\hline 193 & 7,24 & Kaolinit & 001 & 0,600 & 139,13 \\
\hline
\end{tabular}




\section{MAKALAH ILMIAH}

\begin{tabular}{|c|c|c|c|c|c|}
\hline $\begin{array}{c}\text { Kedalaman } \\
(\mathrm{m})\end{array}$ & $\begin{array}{c}\text { Ketebalan Unit Sel } \\
\text { (d spacing) }\end{array}$ & Mineral Lempung & 00\lceil & ${ }^{0} \Delta 2 \theta$ & $\mathbf{L}$ \\
\hline & 4,43 & & 002 & 0,300 & 280,65 \\
\hline \multirow{2}{*}{198} & 7,24 & \multirow{2}{*}{ Kaolinit } & 001 & 0,600 & 139,13 \\
\hline & 4,43 & & 002 & 0,300 & 280,65 \\
\hline 222 & 2,99 & Smektit & 003 & 0,300 & 286,36 \\
\hline \multirow{2}{*}{239} & 7,10 & \multirow{2}{*}{ Kaolinit } & 001 & 0,300 & 278,25 \\
\hline & 4,43 & & 002 & 0,200 & 420,98 \\
\hline \multirow{3}{*}{243} & 4,45 & \multirow{2}{*}{ Smektit } & 002 & 0,500 & 168,52 \\
\hline & 3,01 & & 003 & 0,200 & 429,54 \\
\hline & 3,49 & Kaolinit & 002 & 0,200 & 420,98 \\
\hline \multirow{3}{*}{250} & 9,94 & \multirow{3}{*}{ Illit } & 001 & 0,500 & 166,47 \\
\hline & 4,41 & & 002 & 0,300 & 280,78 \\
\hline & 3,35 & & 003 & 0,200 & 426,25 \\
\hline \multirow{2}{*}{252} & 4,45 & \multirow{2}{*}{ Smektit } & 002 & 0,400 & 210,65 \\
\hline & 3,01 & & 003 & 0,300 & 286,36 \\
\hline
\end{tabular}

Keterangan:

00 : Basal Ke-1,2, 3,...dst

${ }^{0} \Delta 2 \theta \quad$ : Derajat Kristalinitas

L : : Ukuran Butir Kristal (nm)

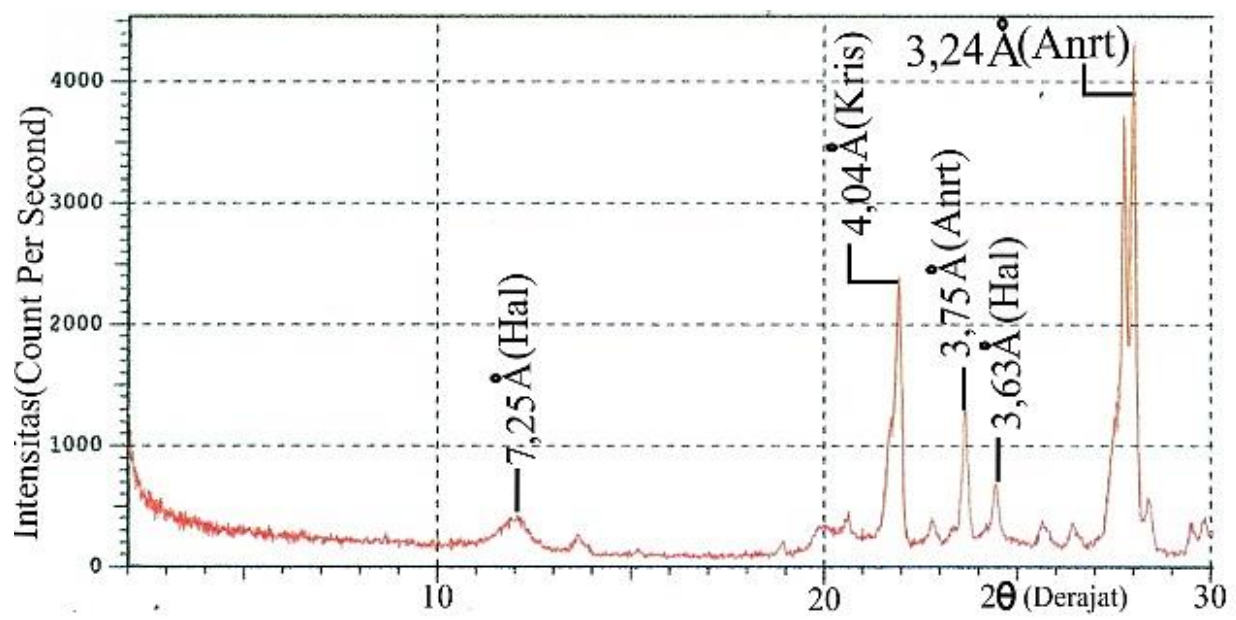

Keterangan: Anrt = Anortit; Hal $=$ Haloisit Kris $=$ Kristobalit

Gambar 6. Analisis XRD dikedalaman $121 \mathrm{~m}$ pada sumur LW-2

Keberadaan haloisit pada sumur penelitian, didukung juga oleh hasil petrografi yang menunjukkan adanya haloisit dengan ciri berukuran sangat halus dan umumnya hadir mengubah massa dasar gelas dan fenokris plagioklas (Gambar 7).

Pada sumur LW-1 dan LW-2, kehadiran Illit tersebar secara tidak merata seperti yang ditunjukkan pada Gambar 4 dan Gambar 5. Hasil analisis XRD di kedalaman $250 \mathrm{~m}$ pada sumur LW-2, menunjukkan bahwa kemunculan illit berada di 9,94 $\AA$ untuk basal pertama, basal kedua berada di 4,41 $\AA$ sedangkan untuk basal ketiga, illit muncul pada 3,35 $\AA$ (Gambar 8).
Illit merupakan mineral hasil ubahan plagioklas dan gelas yang hadir mengisi rongga-rongga (vugs) pada batuan, seperti tampak pada hasil analisis petrografi pada sumur LW-2 di kedalaman $250 \mathrm{~m}$ yang menunjukkan kehadiran illit dengan dicirikan oleh bentuk serabut berwarna kekuningan dengan bias rangkap rendah yang hadir mengisi rongga (vug) dan sebagian besar merupakan ubahan massa dasar gelas (Gambar 9). Illit merupakan mineral yang terbentuk pada kondisi larutan ber-pH netral hingga sedikit asam (Kingston Morrison Ltd, 1995) dengan temperatur pembentukan berkisar antara $220^{\circ} \mathrm{C}$ s.d. $300^{\circ} \mathrm{C}$ (Reyes, 1990). 

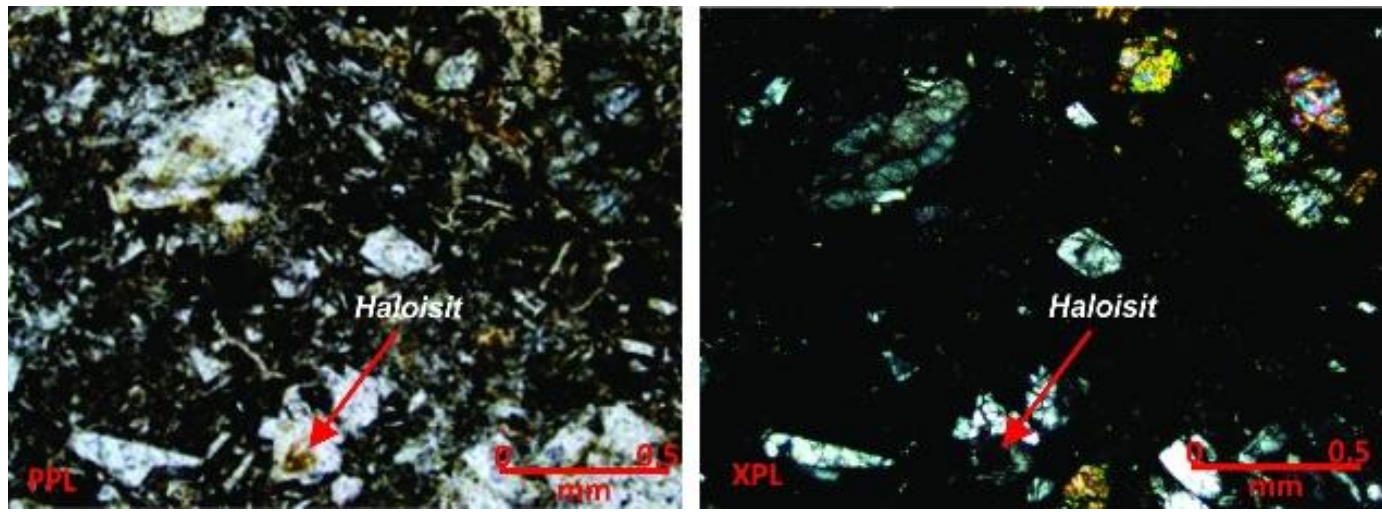

Gambar 7. Keberadaan haloisit hadir mengubah massa dasar

dan fenokris plagioklas di kedalaman $121 \mathrm{~m}$ pada sumur LW-2

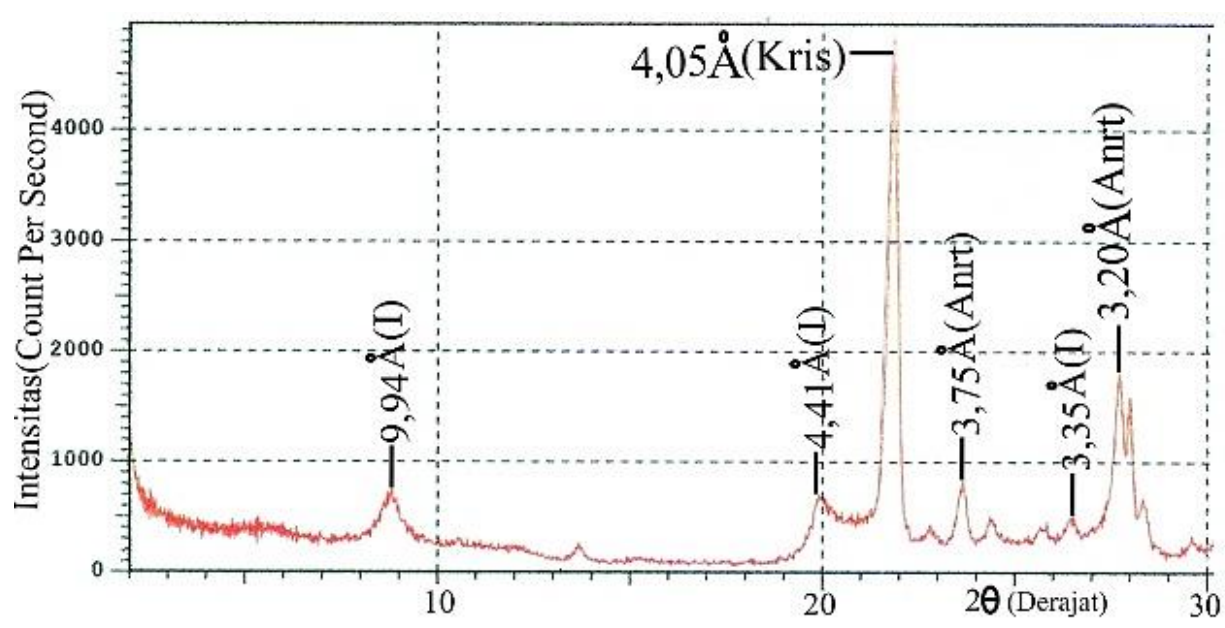

Keterangan : Anrt $=$ Anortit $; \mathrm{I}=$ Illit $;$ Kris $=$ Kristobalit

Gambar 8. Analisis XRD di kedalaman 250 m pada sumur LW-2
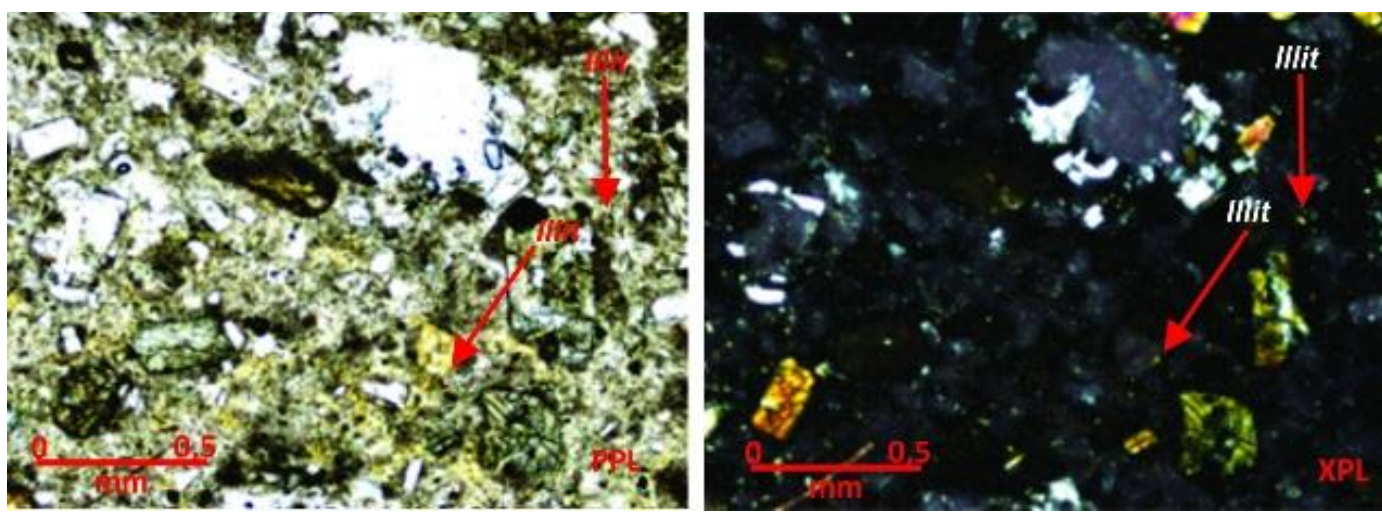

Gambar 9. Kenampakan illit yang sebagian besar hadir mengubah massa dasar gelas vulkanik pada kedalaman $250 \mathrm{~m}$ di sumur LW-2

Keberadaan kaolinit di sumur LW-1 hadir secara setempat, namun pada sumur LW-2 kaolinit hadir lebih dominan dibandingkan dengan sumur LW-1 (Gambar 4 dan Gambar 5). Secara umum, pola XRD untuk kaolinit pada basal pertama berada sekitar $7,13 \AA$, sedangkan pada basal kedua berkisar di $4,43 \AA$ dan untuk basal ketiga berada di sekitar 3,61 $\AA$ (Gambar 10). Secara mikroskopis, kaolinit dicirikan berbentuk serabut kekuningan dengan bias rangkap rendah, keruh dan tampak mengubah plagioklas dan gelas vulkanik, seperti yang ditunjukkan pada 
sumur LW-1 di kedalaman 128 m (Gambar 11). Kaolinit merupakan mineral lempung yang memiliki temperatur pembentukan hingga $220^{\circ} \mathrm{C}$ pada kondisi larutan $\mathrm{pH}$ asam (Reyes, 1990) dan digunakan sebagai penciri zona argilik oleh Corbett dan Leach (1998). Kaolinit dan haloisit terbentuk pada temperatur rendah yang dapat mengindikasikan adanya proses interaksi batuan dengan fluida asam.

Smektit hadir secara dominan pada setiap kedalaman yang terdapat pada sumur LW1 dan sumur LW-2 (Gambar 4 dan Gambar 5). Pada sumur LW-1, smektit mulai hadir di kedalaman $13 \mathrm{~m}$ dan intensif hadir kembali pada kedalaman $70 \mathrm{~m}$. Sedangkan di sumur LW-2, kemunculan smektit teramati mulai pada kedalaman 106,6 m dan pada kedalaman yang lebih dalam yaitu pada kedalaman $140 \mathrm{~m}$, smektit hadir secara berlimpah. Smektit merupakan mineral lempung yang mudah diidentifikasi melalui analisis XRD. Pada basal pertama, smektit menunjukkan pola XRD pada kisaran 14,96 $\AA$ s.d. $15,49 \AA$, sedangkan pada basal kedua berada pada kisaran

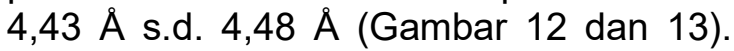
Pengamatan secara mikroskopis di kedalaman $234 \mathrm{~m}$ pada sumur LW - 1, menunjukkan smektit dicirikan oleh warna abu-abu - coklat pucat dan merupakan hasil ubahan dari plagioklas, piroksen serta gelas vulkanik (Gambar 14).

Kehadiran smektit merupakan hasil proses argilitisasi terhadap mineral primer seperti plagioklas, piroksen dan gelas vulkanik yang terbentuk pada temperatur rendah yaitu sekitar $180^{\circ} \mathrm{C}$ (Reyes, 1990), serta dapat digunakan sebagai penciri tipe zona ubahan argilik (Corbett dan Leach,1998).

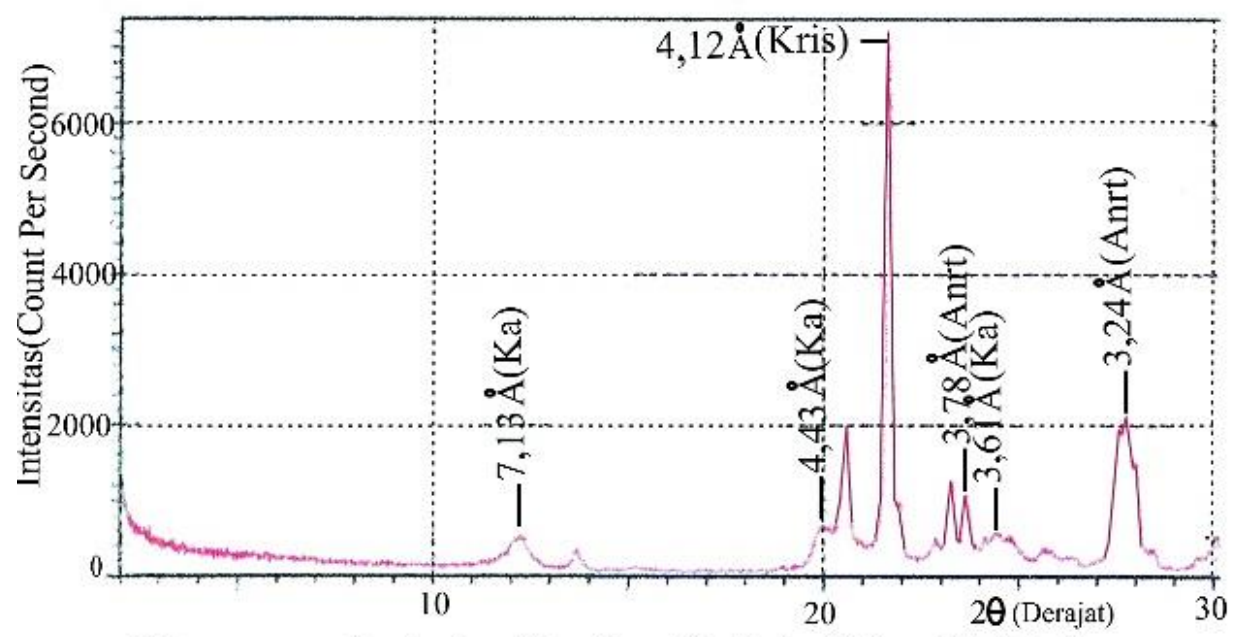

Keterangan : Anrt $=$ Anortit $; \mathrm{Ka}=$ Kaolinit $; \mathrm{Kris}=$ Kristobalit

Gambar 10. Analisis XRD di kedalaman $128 \mathrm{~m}$ pada sumur LW-2
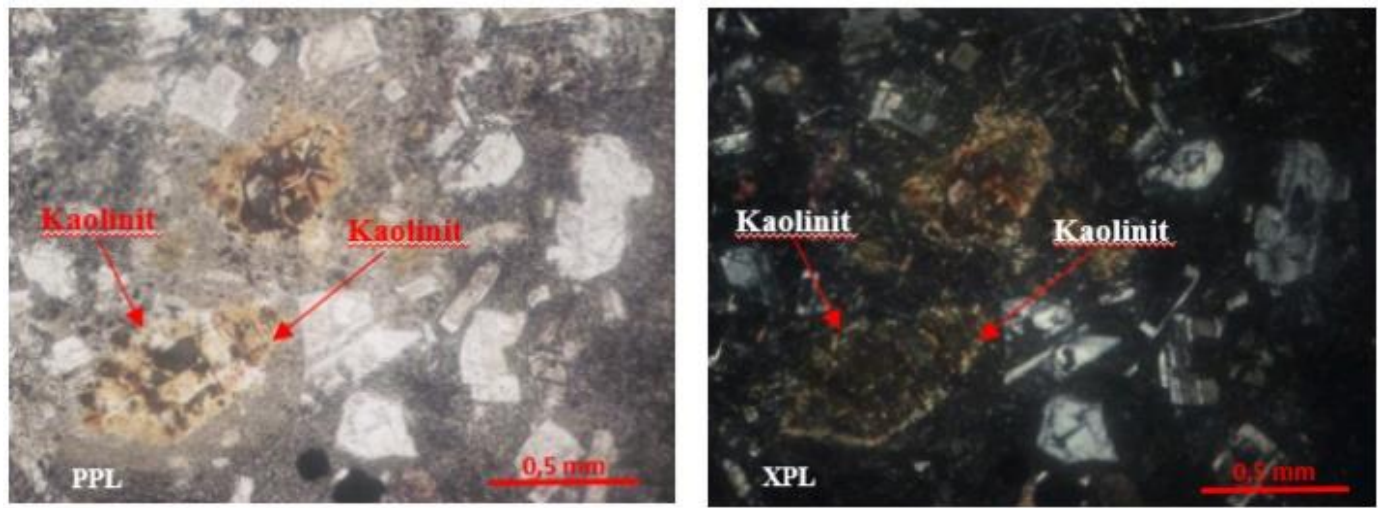

Gambar 11. Kaolinit hadir mengubah mineral mafik dan felsik

di kedalaman $128 \mathrm{~m}$ pada sumur LW-2 


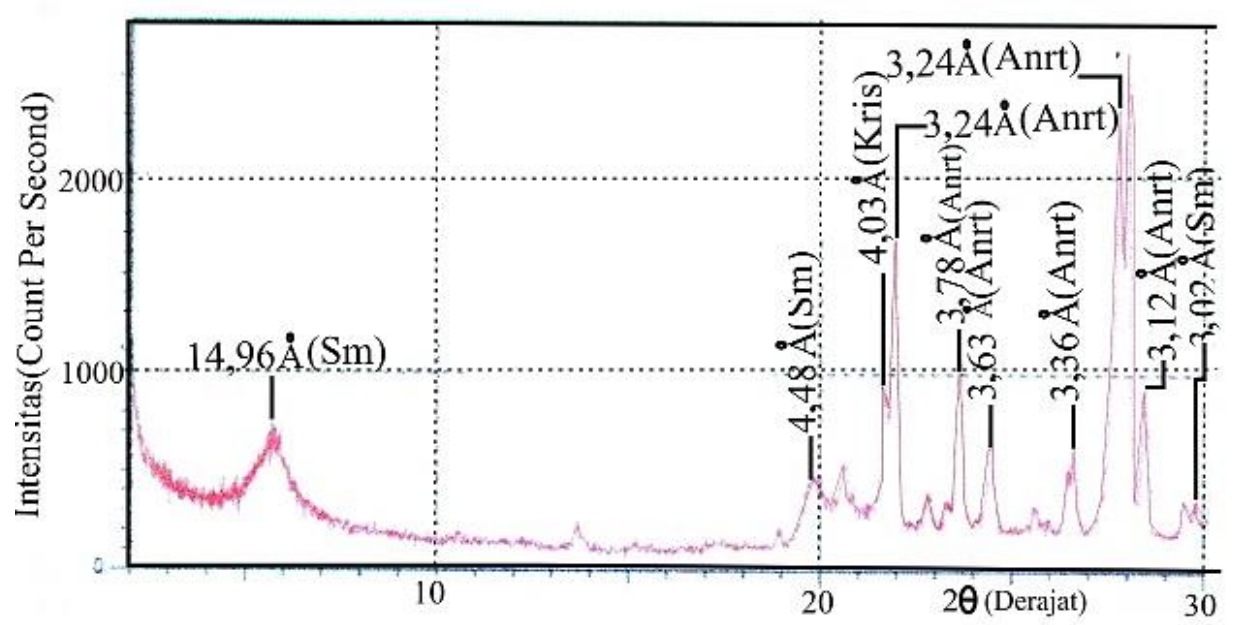

Keterangan : Anrt $=$ Anortit $;$ Kris $=$ Kristobalit $; \mathrm{Sm}=$ Smektit

Gambar 12. Analisis XRD di kedalaman $201 \mathrm{~m}$ pada sumur LW-1

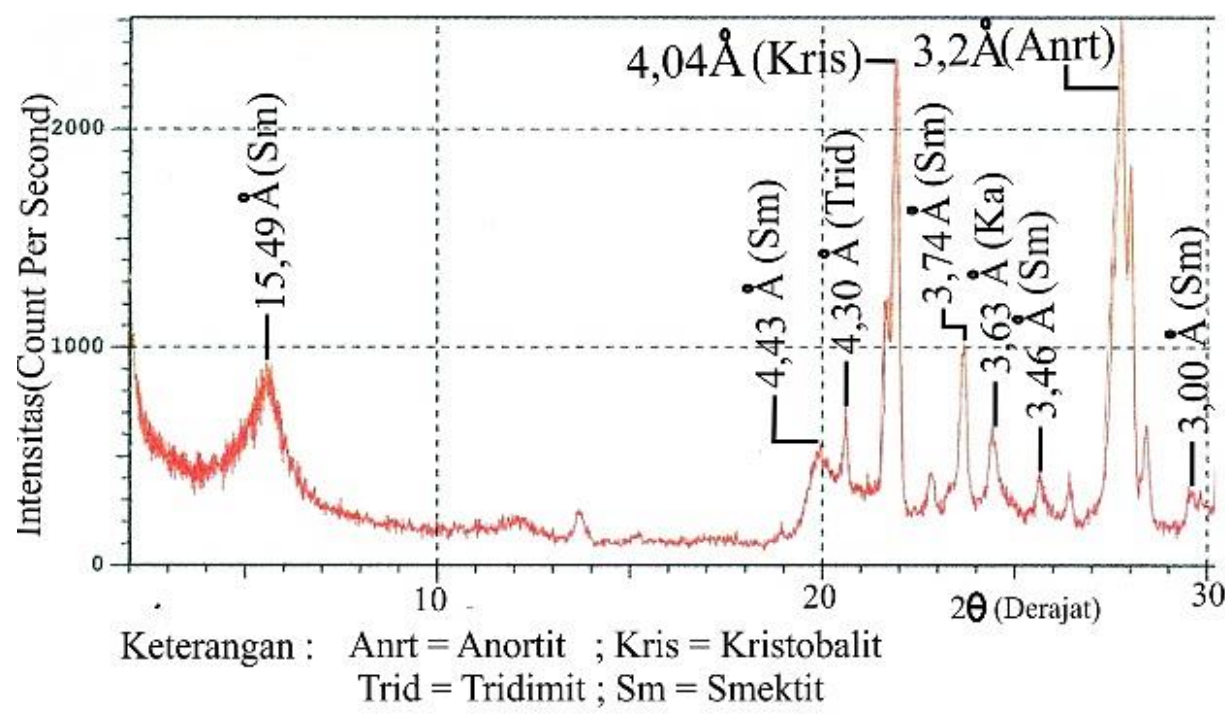

Gambar 13. Analisis XRD di kedalaman $234 \mathrm{~m}$ pada sumur $\mathrm{LW}-1$
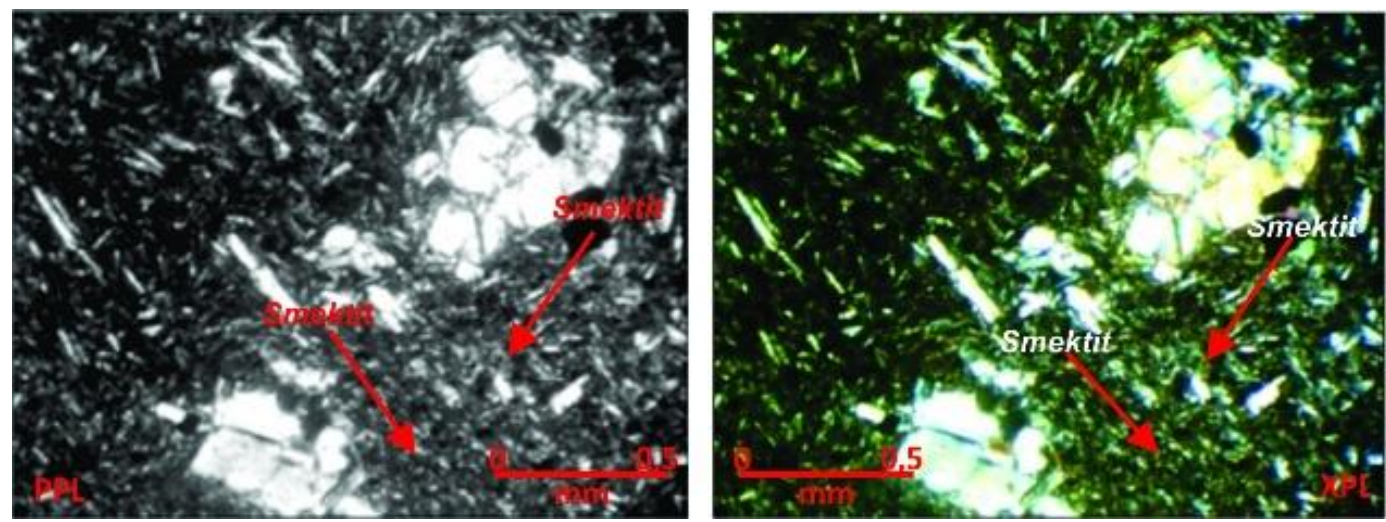

Gambar 14. Smektit hadir mengubah mineral mafik pada kedalaman $234 \mathrm{~m}$ di sumur LW-1 


\section{MAKALAH ILMIAH}

Hasil pengolahan data XRD dengan menggunakan derajat kristalinitas (Tabel 1), menunjukkan bahwa pada sumur LW-1 memiliki nilai ${ }^{0} \Delta 2 \theta$ sekitar 0,1 s.d. 0,9 , sedangkan pada sumur LW-2 nilainya berkisar 0,2 s.d. 0,9. Ma, dkk (1992) menjelaskan bahwa nilai indeks Kubler cenderung akan mengecil seiring dengan adanya peningkatan temperatur dan kedalaman, hal tersebut sesuai dengan rentang nilai ${ }^{0} \Delta 2 \theta$ yang terdapat pada kedua sumur di daerah penelitian.

Selain derajat kristalinitas, melalui hasil analisis XRD dapat juga diperoleh ukuran butir suatu kristal dengan menggunakan persamaan Scherrer (Fitriyana,dkk., 2018), yaitu :

$L=\frac{57.3 x k x \lambda}{F W H M x \cos \theta}$

dengan :

$\mathrm{L}=$ ukuran butir kristal $(\mathrm{nm})$

$\mathrm{k}=$ konstanta oksida $(0,94)$

$\lambda=$ panjang gelombang sinar- $X$ $(1,5406 \AA)$

FWHM = Full Width Half Maximum

$\left({ }^{0} \Delta 2 \theta\right.$; lihat Tabel 1$)$

$\theta=$ sudut posisi puncak difraksi kristal

57,3 = faktor koreksi dari derajat ke radian

Hasil perhitungan ukuran butir kristal pada sumur LW-1 dan LW-2 menunjukkan bahwa smektit memiliki ukuran butir sekitar 92,33 nm s.d. 429,54 nm, sedangkan illit mempunyai ukuran butir berkisar 166,47 $\mathrm{nm}$ s.d. $426,25 \mathrm{~nm}$. Sementara itu, untuk kaolinit dan haloisit secara berurutan memiliki ukuran berkisar $92,75 \mathrm{~nm}$ s.d. $849,13 \mathrm{~nm}$ dan 104,30 nm. Secara lengkap, hasil perhitungan ukuran butir kristal pada sumur LW-1 dan LW-2 dengan menggunakan formulasi Scherrer tersaji pada Tabel 1.

Ji dan Browne (2000) menyebutkan bahwa perubahan struktur kristal mineral lempung sangat dipengaruhi oleh faktor temperatur. Hal tersebut tampak pada saat temperatur mengalami peningkatan maka bentuk kistal dari mineral lempung semakin sempurna yang kemudian diikuti oleh semakin kecilnya nilai ${ }^{0} \Delta 2 \theta$. Dalam hal ini, sumur LW-1 dan LW-2 memiliki kecenderungan nilai ${ }^{0} \Delta 2 \theta$ yang semakin mengecil seiring dengan peningkatan temperatur dan bertambahnya kedalaman, seperti yang terlihat pada Gambar 15 dan Gambar 16.

Pengaruh ukuran butir pada pola XRD menunjukkan bahwa derajat kristalinitas mineral lempung cenderung mengalami penurunan seiring dengan bertambahnya ukuran butir (Gambar 17). Hal tersebut sesuai dengan yang diungkapkan oleh Frey, 1986 (dalam Ma, dkk., 1992) yang menjelaskan bahwa semakin kasar bentuk butir kristal maka akan cenderung semakin terkristalisasi, sehingga dapat menyebabkan menurunnya nilai derajat kristalinitas.

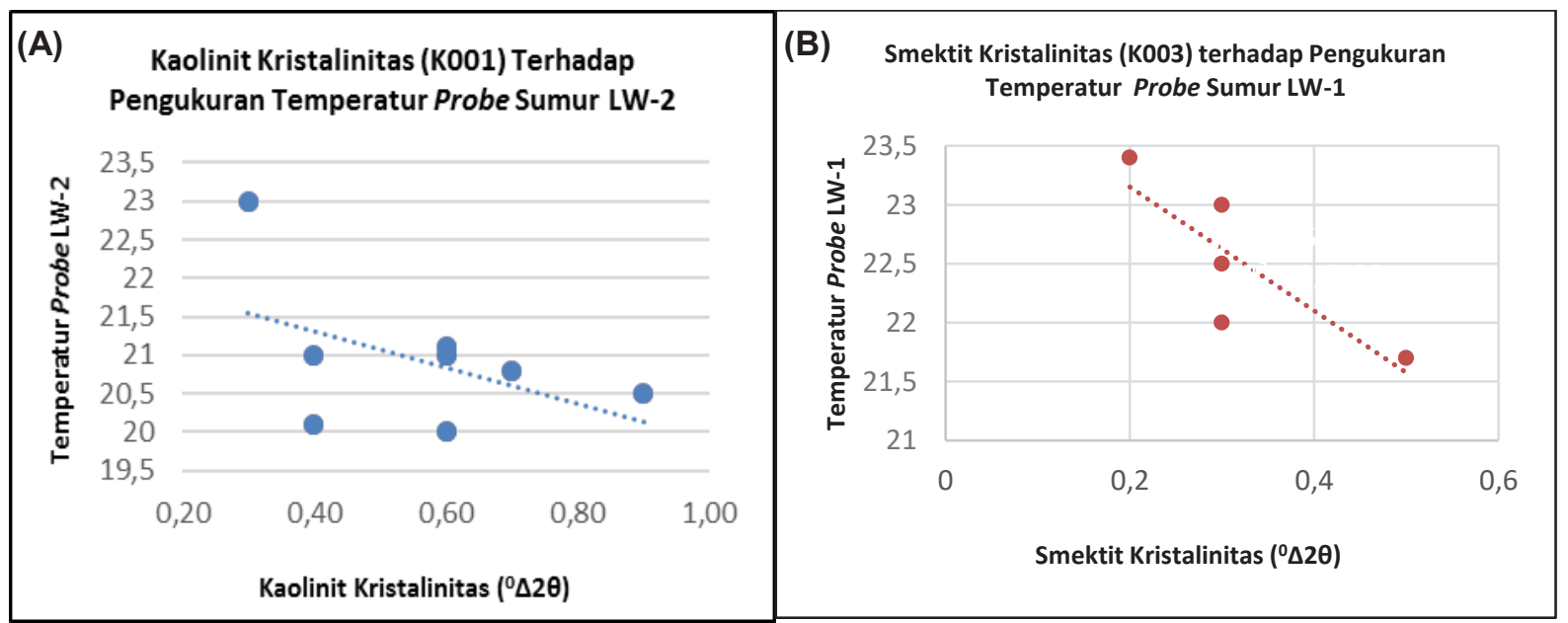

Gambar 15. Grafik hubungan antara derajat kristalinitas dan temperatur di sumur LW-2 (A) dan LW-1 (B) 


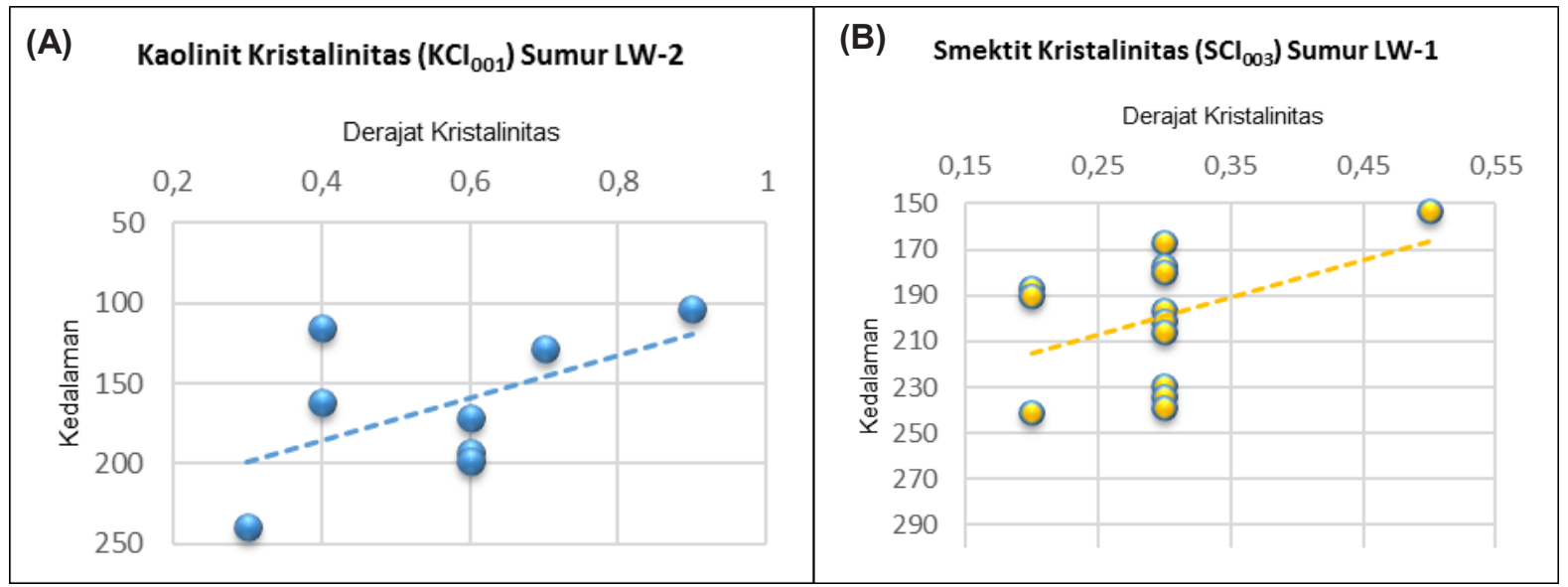

Gambar 16. Grafik hubungan antara derajat kristalinitas dan kedalaman di sumur LW-2 (A) dan LW-1 (B)
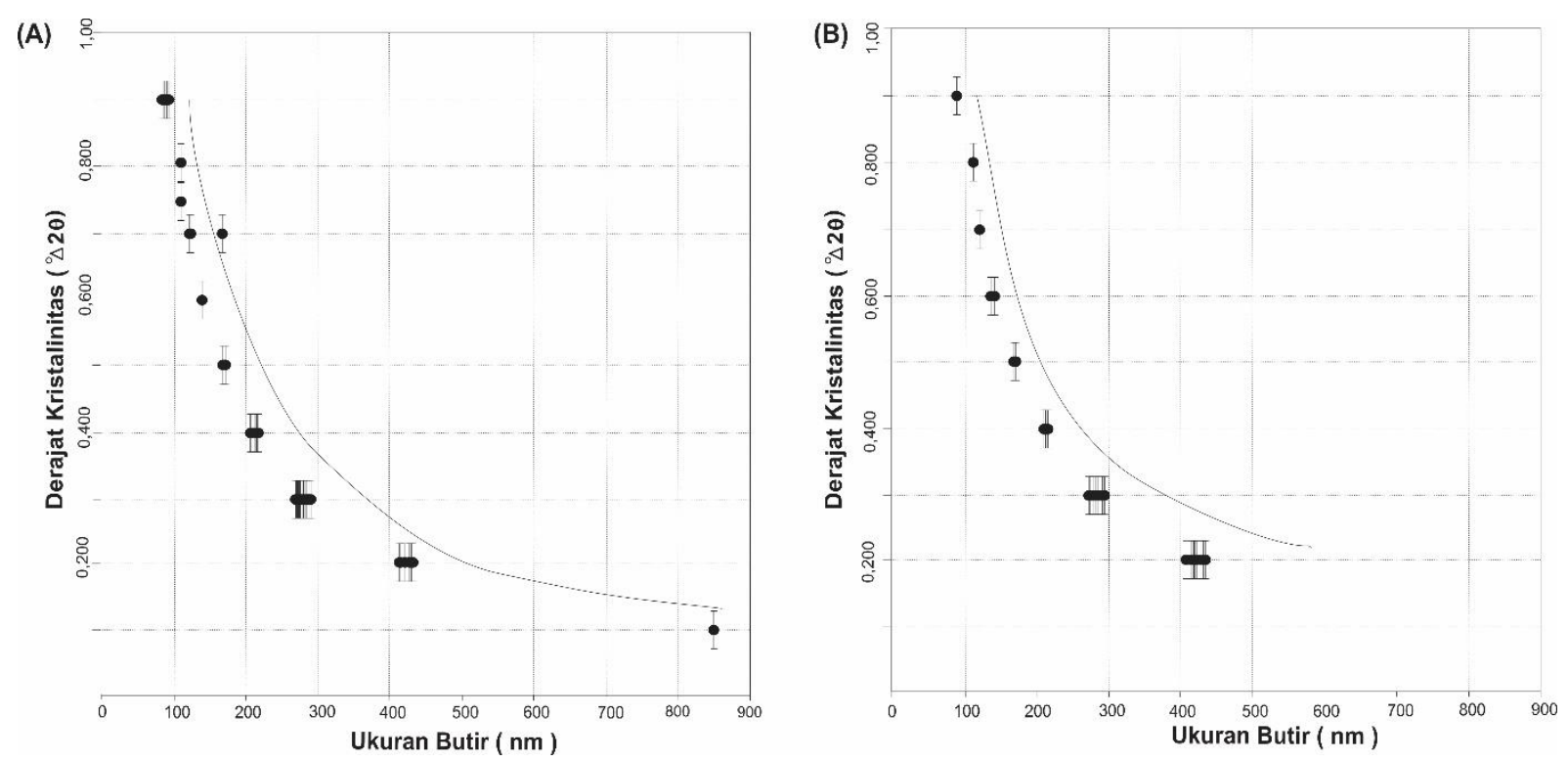

Gambar 17. Variasi pola XRD berdasarkan perbedaan ukuran butir pada sumur LW-1 (A) dan sumur LW-2 (B). Simbol (\$) menunjukkan lebar pada setengah intensitas maksimum terhadap ukuran butir, sedangkan garis penuh (-) menunjukkan trend dari variasi pola XRD berdasarkan perbedaan ukuran butir

Mineral lempung hasil ubahan yang terdapat pada sumur LW-1 dan LW-2 dipengaruhi oleh dua jenis fluida hidrotermal yakni fluida asam dan fluida netral. Hal tersebut tampak dari kehadiran kaolinit dan haloisit di sumur LW-1 dan LW2 yang mengindikasikan adanya fluida asam di masa lampau, seperti yang diungkapkan oleh Kingstone Morrison (1995). Keterdapatan fluida asam ini diduga merupakan hasil proses kondensasi pada kedalaman yang dangkal. Sedangkan, keberadaan smektit mencirikan kemungkinan adanya pengaruh fluida netral pada sumur LW-1 dan LW-2.

Pada sumur LW-2, kehadiran haloisit di kedalaman $121 \mathrm{~m}$ (Gambar 7), Illit pada kedalaman 250 m (Gambar 9) dan kaolinit di kedalaman $128 \mathrm{~m}$ (Gambar 11) serta smektit pada kedalaman 234 m di sumur LW-1 (Gambar 14), mengindikasikan bahwa pada sumur penelitian telah terjadi interaksi antara fluida hidrotermal dan batuan yang dilewatinya, terutama batuan vulkanik Gunung Lawu. Hal tersebut 
tercermin dari adanya mineral piroksen, plagioklas dan gelas vulkanik yang terubah menjadi mineral lempung.

Kehadiran mineral lempung yang terdapat pada sumur LW-1 dan LW-2 dapat digunakan sebagai indikator temperatur bawah permukaan pada saat mineral tersebut terbentuk. Keberadaan smektit mencirikan pembentukan temperatur masa lampau di daerah penelitian sekitar $180^{\circ} \mathrm{C}$, sedangkan illit menandakan bahwa temperatur masa lampau lebih dari $220^{\circ} \mathrm{C}$. Sementara itu, kehadiran haloisit dan kaolinit secara berurutan memiliki pembentukan temperatur masa lampau sekitar kurang dari $120^{\circ} \mathrm{C}$ dan kurang dari $220^{\circ} \mathrm{C}$. Namun demikian, hasil pengukuran logging temperatur pada sumur LW-1 dan LW-2 (Gambar 4 dan Gambar 5) menunjukkan temperatur antara $16^{\circ} \mathrm{C}$ s.d. $25^{\circ} \mathrm{C}$. Adanya perbedaan antara kondisi temperatur saat ini berdasarkan hasil logging dengan temperatur pada saat mineral lempung hasil ubahan terbentuk, memperlihatkan bahwa telah terjadi pendinginan (cooling) pada sistem hidrotermal di daerah penelitian yang diduga akibat air meteorik yang masuk kedalam zona aliran kondensasi.

Keterdapatan mineral lempung pada sumur LW-1 dan LW-2 berfungsi sebagai lapisan penudung (caprock) pada sistem panas bumi Gunung Lawu. Lapisan penudung ini memiliki resistivitas listrik rendah sebagai akibat adanya kehadiran beberapa mineral hasil ubahan hidrotermal terutama mineral lempung. Anonim (2010c) menyebutkan bahwa berdasarkan data magnetotelurik, lapisan penudung di daerah penelitian berada di dekat permukaan hingga elevasi sekitar $0 \mathrm{~m}$. Keberadaan lapisan penudung di daerah penelitian yang kaya akan mineral lempung hasil ubahan, seperti smektit, illit, kaolinit dan haloisit merupakan salah satu elemen penting dalam terbentuknya sistem panas bumi Gunung Lawu. Hal tersebut disebabkan oleh karakterisitik lapisan penudung yang bersifat impermeable, sehingga dapat mencegah keluar atau bocornya fluida panas bumi dari reservoir ke permukaan.

\section{KESIMPULAN}

Penggunaan metode XRD pada sumur LW-1 dan LW-2 dapat memberikan petunjuk tentang derajat kristalinitas dan hubungannya terhadap temperatur serta ukuran butir kristal. Mineral lempung hasil ubahan hidrotermal di daerah penelitian terdiri dari smektit, illit, kaolinit dan haloisit yang berfungsi sebagai lapisan penudung pada sistem panas bumi Gunung Lawu.

\section{UCAPAN TERIMA KASIH}

Ucapan terima kasih penulis sampaikan kepada Kepala Bidang Panas Bumi, Pusat Sumber Daya Mineral Batubara atas penggunaan data dalam penulisan makalah ini. Penulis juga mengucapkan terima kasih kepada Sdri. Tatik Handayani, S.T.,M.T yang telah membantu dalam penyediaan data sekunder dan tim editor yang telah memberikan koreksi serta saran dalam penyusunan makalah ini.

\section{DAFTAR PUSTAKA}

Anonim, 2009. Survei Terpadu Geologi dan Geokimia Daerah Panas Bumi Gunung Lawu, Provinsi Jawa Tengah dan Jawa Timur. Pusat Sumber Daya Geologi - Badan Geologi, Bandung.

Anonim, 2010a. Pengeboran Landaian Suhu Sumur LW-1 Daerah Panas Bumi Gunung Lawu, Kabupaten Karang Anyar, Provinsi Jawa Tengah. Pusat Sumber Daya Geologi - Badan Geologi, Bandung.

Anonim, 2010b. Pengeboran Landaian Suhu Sumur LW-2 Daerah Panas Bumi Gunung Lawu, Kabupaten Magetan, Provinsi Jawa Timur. Pusat Sumber Daya Geologi - Badan Geologi, Bandung.

Anonim, 2010c. Survei Magnetotellurik Daerah Panas Bumi Gunung Lawu, Kabupaten Karang Anyar, Provinsi Jawa Tengah dan Kabupaten Magetan, Provinsi Jawa Timur. Pusat Sumber Daya Geologi - Badan Geologi, Bandung. 
Browne, P.R.L., 1999. Hydrothermal alteration, 665.611 Lectures Notes. Geothermal Institute, University of Auckland.

Corbett G. J. dan Leach T.M., 1996. Southwest Pasific $\mathrm{Rim} \mathrm{Au} / \mathrm{Cu}$ System: Structure, Alteration and Mineralization. Workshop Manual, 186 hal.

Eberl, D.D dan Velde, B., 1989. Beyond the Kubler Index. Clay Miner, vol 24,571577.

Fitriyana,D.F., Sulardjaka, Iskandar,N., dan Dzulfikar,M.,2018. Pengaruh Suhu Hidrotermal Terhadap Karakteristik Zeolit yang Disintesis dari Lembah Geotermal. Majalah IImiah Momentum, Vol. 14, No. 1, Hal. 4650.

Hamilton, W.B.,1979. Tectonics of Indonesian Region, USGS Profesional Paper 1078.

Ji,J dan Browne, P.R.L, 2000. Relationship Between Illite Crystallinity and Temperature in Active Geothermal System of New Zealand. Clays and Clay Minerals, Vol. 48, No. 1, 139144.

Kingston Morrison, 1995. Important Hydrothermal Minerals and Their Significance. Geothermal and mineral services division. Kingston Morrison Ltd, edisi ke 6.
Ma, C., Browne, P.R.L. dan Harvey, CC., 1992. Crystallinity of Sub Surface in The Te Mihi Sector of The Wairakei Geothermal System, New Zealand. Proceeding New Zealand Geothermal Workshop 14 th, 267272.

Moore, D.M. dan Reynolds, Jr, R.C., 1997 : X-ray diffarction and The Identification and Analysis of Clay Minerals. Oxford University Press, 332 hal.

Permana, L.A., 2011. Studi Karakteristik Mineral Ubahan Pada Sumur LW-1 dan LW-2 di Daerah Panas Bumi Gunung Lawu. Tesis. Departemen Teknik Geologi - Institut Teknologi Bandung. Tidak dipublikasikan.

Prasetyo,I,M., Sardiyanto, Koestono,H., dan Thamrin,M.H., 2015. Clay Alteration Study from Wells of Tompaso Geothermal Field, North Sulawesi, Indonesia. Proceedings World Geothermal Congress, Melbourne, Australia.

Reyes, A.G., 1990. Petrology of Philipine Geothermal Systems and The Application of Alteration Mineralogy to Their Assessment. Journal Vulcanology and Geothermal, vol 43, 279-309.

\begin{tabular}{|ll|}
\hline Diterima & $:$ : Januari 2020 \\
Direvisi & $: 30$ Maret 2020 \\
Disetujui & $:$ 22 April 2020 \\
\hline
\end{tabular}

